\title{
Thoughts on Development Patterns Choice of Minority Music and Dance
}

\author{
Yonghui Li
}

School of music and dance, Qujing Normal University, Qujing Yunnan, 655000, China

\author{
Keywords: Minority, Musical dance, Development patterns, Choice.
}

\begin{abstract}
With the continuous progress of the times, the development model minority music and dance of much attention in the community. Minority music and dance has a long history, is an important component part of China's outstanding traditional national culture. In recent years, ethnic music and dance development is worrying. According to the actual article, combined with literature, discusses the basic position in the important Chinese music and dance on the minority from Yunnan Ethnic Culture School mode, Yang "Yunnan" mode, the national stage to promote minority music original ecological development model, Minority cultural music and dance mode propagation Plaza Chengdu, Guizhou University Art College minority music and dance education model five aspects of a comprehensive thinking, and to the protection of fine traditional culture of ethnic minorities helpful.
\end{abstract}

\section{Introduction}

At present, the social and economic development constantly, ethnic music and dance more and more by the community's attention. And the protection of minority music and dance heritage in terms of its mode, direction, goals, etc. has high demands. In recent years, the development model minority music and dance of choice has become another important task for the protection of minority and cultural heritage of our country before. Combining the actual case, the original ecology of music to promote minority development model from the important position of the Chinese Ethnic music and dance, Yunnan Ethnic Culture School mode, Yang "Yunnan" mode, the national stage, Chengdu Minority Music Square cultural transmission dance mode and other aspects are discussed in detail, it aims to make an important share.

\section{The importance of China's ethnic minority music and dance}

Minority music and dance are an important part of the Chinese nation's cultural treasures, ethnic music and dance are an important way to reflect the cultural identity of minorities, ethnic music and dance of all ethnic groups is a tool for communication. [1]. As we all know, our country is multi-ethnic country, after the millennium, every nation there are unique and valuable excellent music and dance. Minority music and dance to a large extent reflects the various ethnic groups living habits, body language, and ethnic customs and so on. As we all know, art is not subject to time, place, language and other restrictions, which contains a common, plays a role should not be overlooked in the national communication, communication, and in maintaining national unity. The presence of minority music and dance art, aesthetically pleasing visual, auditory, to improve people's quality of life, improvement of people's aesthetic taste and is very helpful.

\section{Model Minority Chinese music and dance of today's development choices}

\section{Yunnan Ethnic Culture School Model}

Idea 
In 1990s, Yunnan Ethnic Culture School officially founded, well-known composer Yutaka is its founder. ECS mainly uses the method of recruitment in order to strengthen the members, high prestige and wise folk artists of the national culture harbor deep feelings of love Teen Students of. Among them, the teen participants must grasp and understand the national traditional culture, its heritage education, art appreciation, folklore, ethnic history. Information on music heritage, its cultural and ecological environment, relying on large, ECS members In the study, the arbitration must, breeding animals. In addition, the Yunnan Ethnic Culture School in two-way communication has taken on, "Please come, sent down" approach. "Please come" refers to the invitation, and the wise folk artists hired to lecture hall, exchange, teach, students get to promote systematic, comprehensive, centralized traditional knowledge. At the same time, the museum researchers can phone research related information; "sent down" refers to a teaching museum researchers, students in a batch form to narrow the traditional culture to its investigation, analysis, and recording. Be graduate students, a small number of people engaged in the work in their hometowns (communication, development of traditional culture) and traditional culture-related, most people leave teaching museum. Yunnan Nationalities ECS dynamic (show-man show) and static (display items) culture combine [2], people from the auditory, visual, sensory experience of three aspects, perception charm of traditional culture. The establishment of National Biography House, of all ethnic groups has a positive effect: the protection of cultural heritage and promote economic development.

\section{Actual operation}

The actual operation and philosophy there are differences. ECS members come from recruitment, probation for six months, during which participants must solve their own living expenses. To be completed probation and qualified, students get a certain economic subsidies. For ECS source of income is concerned, including personal, social and all sponsorship. Thus, the ECS in the operation has insufficient funds. To improve the quality of life of students, the honors student Yutaka into ensembles, cultural traditions inherited gradually shift towards market orientation performance demands. Reality intruded, Yunnan folk culture through diet failed in the establishment of the seventh year. Yunnan Folk Culture School to give us a lesson: activation heritage, correctly handle the relationship changed and unchanged.

\section{Yang Liping's Yunnan image mode}

"Yunnan Impression" Once the show, has aroused great attention of society, it is to promote the efficient development of the cultural industry in Yunnan successful model. "Yunnan Impression" in the protection of minority music and dance heritage and the arts made such remarkable results, mainly due to the following three reasons: 1, dig culture. "Yunnan Impression" as a successful example of national culture heritage, greatly boosted the development of industry in Yunnan region. "Yunnan Impression" generation, took many famous dancer Yang Liping effort by long distance trips, combined with modern sound, lighting, stage and so on, it took more than a year of training and, ultimately, people showing visual auditory gluttonous feast. "Yunnan Impression" dance in part by seven games (fire, clouds, forest, and Japan) the composition [3], its actors, mostly from the original ecological Village, villages, fields to first class, in strong local flavor on the stage performance of the head . In addition, the "Yunnan Impression" full of brilliant colors, different body language and other ethnic minorities. At the same time, the "Yunnan Impression" using props, costumes, music mused from ethnic minorities. "Yunnan impression" on the content of the layout step by step, the audience raised a profound reflection, full of original ecological beauty of Yunnan minorities. "Yunnan Impression" is the original ecosystem, instead of the original crude, which was established in the fine Chinese tradition above, and a blend of modern folk, gives a "physical, mental and Heaven" shock. (2) Operation of the market and rely on business investment. "Yunnan Impression" to meet the performance needs of the market, in line with social progress and economic development, are products of the project areas. "Yunnan Impression" of success mainly because of its take to establish brand, improve the operating mechanism, three measures to increase the marketing propaganda. (3) government policy support. On the "Yunnan Impression", the Government's policy support is also 
essential to their. "Yunnan Impression" to minority music and dance heritage protection and the idea can be summarized, summed up as "government guidance, enterprise investment and operation of the market."

\section{National music stage to promote minority original ecological development model}

National stage is a stage art form, which is supported by the government, national financial and cultural policies. With the deepening of China's national policy of development, ethnic minorities were included in the scope of the nation-state. Strictly speaking, the national stage representing the authority of the nation, its aesthetic can guide the audience, which reflects the national trend of mainstream culture. In general, the national scene by the media, theater, etc., and China Central Television, China National Grand Theatre etc are the national stage. Generally speaking, deducing on the national scene works mostly in line with the requirements of the mainstream culture. The combination of the national scene and minority music and dance, making the minority music and dance has been greatly improved, so that minority music and dance are greatly protected and heritage. Since 2004, ethnic music and dance by China Central Television as a mainstream culture, their social status improved significantly. By organizing a series of minority music and dance competition, we increased the excellent national culture of publicity and promotion. The involvement of the national stage, largely minority music and dance enhances the learner's self-confidence, help to protect and promote the development of minority music and dance. For example: CCTV Young Singer, known for such minority music and dance, to enhance the audience aesthetic taste, cultivate audiences' sentiment has important significance. The national scene and minority music and dance has undergone major changes [4].

\section{Chengdu Square Culture Communication minority music and dance mode}

Chengdu belongs to China's first batch of historical and cultural city range. From the point of view of the number of ethnic minorities, Sichuan ranked second. Exchange between national integration and deepening ethnic minority music and dance on the square culture had a great influence. In addition, the square culture, communication, protection of minority music and dance mode in Chengdu has been widely used. Plaza Chengdu include cultural festivals resistance, two kinds of community, which plays an unparalleled role in the tradition of minority music and dance arts. In recent years, Chengdu cultural festival plaza type rising. Festivals existence of square culture, to provide the public good intimate contact outstanding minority music and dance platform, has extraordinary significance for mobilizing people to participate in cultural activities to enhance the aesthetic taste, a better understanding of the national culture and so on. In addition, various minority as an opportunity for in-depth communication, interaction, and then reached the campaign to promote the minority music and dance development goals.

According to the survey, Chengdu has a large number of community square, which occupies a pivotal position in the spread of urban culture and cultural heritage of minority carrier. According to statistics, ethnic music and dance in some residential areas of Chengdu Square Cultural Palace of working people and the People's Square and other places occupy a large share. Despite the minority music and dance very different, but as long as it meets the propagation simple, Bo eye, it is possible to mobilize the public to learn the enthusiasm, initiative. In Tibetan and Qiang Zhuang pot, for example, in Chengdu, Tibetan, Qiang occupants conducive to building a culture threshold. In addition, Tibetan and Qiang pot Zhuang flexible performance, with strong participation, mass, and easy to learn, help create a warm and cheerful atmosphere. Practice has proved that the Tibetan and Qiang Zhuang pot again have aesthetic heritage aspect, civilians, public sex, public sex, so much the extent of festivals and community plaza favor. Chengdu Culture Communication Plaza satisfy relationships, sharing, media, modes of transmission four conditions, driven in large part to build a harmonious Chengdu process.

\section{Guizhou University College of the Arts Ethnic Music Dance Education Model}


Ethnic Music Dance Guizhou region an important part of national culture, which is conducive to maintaining unity and ethnic minorities, and enhance cohesion. Guizhou University as one of the Northwest Minority College of Music and Dance Music Major art into classroom teaching, and achieved remarkable results. Guizhou University, mainly by taking the following strategies need to minority music and dance heritage: 1 , professional music theory class. The presence of minority music, in addition to making the students' knowledge to enrich and strengthen the sense of music, familiar with local music, but also on teaching has a guiding role. For example: "Overview of the minority Chinese folk music," "Introduction to folk music" and so on; 2, professional vocal music classroom. Guizhou minority region has many excellent solo vocal works, teachers usually "Zhuang folk songs sound crisp", "Red River thirteen bends", "East Lan Wei has set aside each group," "sweet particulars "and other songs as teaching content [5], to promote minority outstanding vocal music filled the classroom, students at mold sentiment, while a wealth of knowledge to better transmission of traditional culture; 3 , professional dance music classroom. In the actual teaching folk dance, music and dance teacher ethnic minorities into teaching content category. Teachers combine teaching content, the goal, the reality of it too, can be purposeful choice "panniers - Yao" and "sculpture memory", "Miao monkey encouraged", "cedar fragrance beef cattle fat", "Zhuang bronze drum "' home style "," ax dance "and fully reflects the spirit of minority dance teaching. In addition, through the organization of dance competitions, regular reporting dance work, etc., in order to check the students of ethnic minorities dance heritage. In short, Guizhou University minority music and dance into the classroom using the model of protection, national culture heritage.

\section{Conclusions}

Preservation and inheritance of minority music and dance has great significance to promoting China's economic and cultural development. Therefore, China should be combined with the actual situation, choose the appropriate model of development and to protect the heritage of outstanding national culture. Articles from Yunnan Ethnic Culture School mode, Yang Liping's "Yunnan image" mode, the national stage to promote minority music original ecological development model, Plaza Chengdu Culture Communication minority music and dance mode, Guizhou University College of the Arts Ethnic Music Dance Arts Education mode five angles minority music and dance development mode selection to do the research. Hoping that China can continue to optimize the development model minority music and dance, and thus enhance the effectiveness of China's cultural industry.

\section{References}

[1] Li Shan, Zheng Jianguo. City Square Cultural and Ethnic music and dance heritage -- taking the development of Chengdu's square culture as an example, Northwest ethnic research, 2013,04:214-217+9.

[2] Zeng Honghua. Let western Guangxi minority music and dance into higher school music classroom - taking Hechi College as an example, Song sea, 2011,04:108-110.

[3] Li Junlei. Xiangxi minority music and dance sports creative fusion research and development, Modern Economic Information, 2014, 22:460-461.

[4] Du Juan, Yang Guolong. Minority folk music, dance resources on pre-professional music teachers' class quality growth - Rethinking pre-professional music course teaching in minority areas, Ginseng flower(2nd),2015,01:155-157.

[5] Zhang Lu. On Chinese Ethnic Folk Music - Review for Sander Nova Chinese Ethnic Folk Dance Music Appreciation, Song sea,2014,02:67-70. 